\title{
Childhood Mishaps and Its Cognizance among Nepalese Mothers of Parsa District for Its Prevention, Small Cross-sectional Study
}

\author{
Sabitri Bhattarai, ${ }^{1}$ Archana Saha ${ }^{2}$ \\ 'National Medical College, Birgunj, Nepal, ${ }^{2}$ Paediatric Nursing, National Medical College, Birgunj, Nepal.
}

\begin{abstract}
Introduction: Several studies have shown that there several unintentional causes for the unwanted childhood accidents. In addition, Nepal demographic health survey via West University of England revealed at 2006 A.D, 11\% death casualties of under- five aged children are due to unintentional injuries ${ }^{1}$. This particular study is extremely useful to health care planner, provider and researcher to have grand design to be produced by government of Nepal, such that; there shall be minimal rate of casualties of deceased children due to accidents.
\end{abstract}

Methods: This study is descriptive cross sectional study carried out in Parsa district of Nepal where the respondents were mother to assess their awareness of cause of childhood accidents and its prevention. Computer software SPSS is use to scrupulous analysis of study where the chi-square test is used with $95 \%$ level of confidence $(p=0.05)$.

Results: Poisoning $96 \%$ cases is the cause of childhood accident unintentionally, followed by $94 \%$ foreign body aspiration, $85 \%$ flame burn. Unsupervised children are more prone to injury than supervised children. Finally and foremost the crucial correlation of parents level of awareness with childhood are as follows; inadequate level of knowledge have higher percentage of accident (58\%), followed by moderately adequate $(32 \%)$ and adequate $(10 \%)$.

Conclusion: This study though done on small scale on small part of Parsa district can play key role to the policy to have vigilantive and supervision power to see the loopholes that need to be detected and dealing in curative manner.

Keywords: accident; childhood ; injuries ;Nepal.

\section{INTRODUCTION}

Mishaps during childhood are sometimes the causes of death. Scrupulous alertness, awareness is extremely important toward child as they become very curious of everything on their surrounding and scientifically there is increment of locomotor and manipulative skills ${ }^{1}$ on their part. An accident always does not occur intentionally, though if seen casually, majority of times it occur due to unintentional act. In addition, it is very difficult to have unnecessary overprotecting and confinement toward child, for their freedom to pursue is their fundamental right. Furthermore, it is the parent duty to understand and act as sentry toward kids as they cannot foresee the danger when they are playing and it the parent who have to wipe out such situation ${ }^{2}$ which is causative factor childhood accident.

According to the study carried out by , WHO 2011, $57 \%$ children were affected from unintentional injuries where male $(73.7 \%)$ are more prone to than female $(40 \%)$, and the causes of injuries seems to be falls $(6 \%)$, drowning $(6 \%)$, poisoning $(6 \%)$, burn $(5 \%) .^{3}$ Several studies add the information that more death and

Correspondence: Ms. Sabitri Bhattarai, Professor, Nursing Director, National Medical College, Birgunj, Nepal. Email: bhattarai. sabitri8@gmail.com, Phone: +977-9841387764. 
disabilities in children are due to childhood accident of which the main causes may be falls, burns, drowning, road side accident, unintentional other injuries, poisoning, etc. ${ }^{3,4,5}$ If there is cognizance of the parent regarding prevention of casualties, and understand their duty by acting as kind of sentry toward the kids while playing, happen to be playing crucial role in reduction of unwanted mishaps of the kids. To certify this, several studies revealed that, ignorance and negligence of parents are the fundamental cause, thus, improvement on awareness for prevention of childhood accident have vital role and despite this majority of mother are unsure of the role and inadequately prepare for it and recognizes the constraints on their accident preventing activity. ${ }^{2,6,7}$

The current study is thus fruitful to several government heath care planner, provider and researcher to make policy which can enhance the awareness among parent to participate actively in the reduction unwanted childhood mishaps.

\begin{tabular}{|lcc|}
\hline $\begin{array}{l}\text { Table 1. Cognizance of } \\
\text { types of childhood accident.(N= 274). }\end{array}$ & \multicolumn{1}{l|}{$\begin{array}{l}\text { mothers } \\
\text { regarding }\end{array}$} & different \\
\hline $\begin{array}{l}\text { Types of cause for } \\
\text { childhood accident as } \\
\text { aware by mothers }\end{array}$ & $\begin{array}{c}\text { No. of } \\
\text { observation(f) }\end{array}$ & Percentage \\
$\begin{array}{l}\text { Unexpected event } \\
\text { that lead to childhood }\end{array}$ & 222 & 81 \\
accident & & \\
Home accident & 53 & 19 \\
Road side accident & 82 & 30 \\
Sport injury & 49 & 18 \\
Fall injury & 186 & 68 \\
Drowning & 49 & 18 \\
Flame burn & 232 & 85 \\
Ingestion of kerosene, & 263 & 96 \\
insecticides, excessive & & 94 \\
medicines(Poisoning) & & \\
Foreign body aspiration & 257 & \\
\hline
\end{tabular}

\section{METHODS}

This study is descriptive cross sectional study carried out in Pidariguthi V.D.C of Parsa district of Nepal during Baisakh 2072 for one month, where the respondents $(N=274)$ were mother to assess their awareness of cause of childhood accidents and its prevention. Old age mothers were excluded from the study and mother having small kids were considered in the sample. Sampling for this study is via simple random method (lottery method) and data collection procedure is carried with the consent of research department committee of NMC and even the respondents (mothers). In addition, the data were collected by using structured questionnaire with the use of simple Nepali language, if the language not understood then the local language is even used to make them understand fully. Computer software SPSS is use to scrupulous analysis of study where the chi-square test is used with $95 \%$ level of confidence $(p=0.05)$.

\section{RESULTS}

Poisoning seems to have $96 \%$ case of childhood accident which is done unintentionally by ingestion of kerosene, insecticides, and excessive medicines. In addition, foreign body aspiration by curious nature of kids leads into such mishaps as shown in above table by stating of $257(94 \%)$ accidents. Sports injury $18 \%$, home accident $19 \%$, roadside accident $30 \%$, fall injury $68 \%$, flame burn $85 \%$, have shown successive percentage increase to yield into childhood mishaps.

\begin{tabular}{|lcc|}
\hline $\begin{array}{l}\text { Table 2. Cognizance of mothers regarding different } \\
\text { habits of children prone to accident. }(\mathbf{N}=\mathbf{2 7 4}) \text {. }\end{array}$ \\
\hline $\begin{array}{l}\text { Types of habits of } \\
\text { children prone to }\end{array}$ & $\begin{array}{c}\text { No. of } \\
\text { observation(f) }\end{array}$ & Percentage \\
$\begin{array}{l}\text { accident as aware by } \\
\text { mothers }\end{array}$ & & \\
$\begin{array}{l}\text { Unsupervised children } \\
\text { Supervised children }\end{array}$ & 263 & 96 \\
\hline
\end{tabular}

Here it is revealed that the unsupervised children are more $(96 \%)$ prone to injury than supervised children(4\%).

Table 2. Cognizance of mothers regarding different preventive measures for different types of childhood accident. $(\mathbf{N}=\mathbf{2 7 4})$.

\begin{tabular}{llc|}
\hline $\begin{array}{l}\text { Awareness of mothers on } \\
\text { different types of preventive } \\
\text { measures in different types of }\end{array}$ & $\begin{array}{c}\text { No. of } \\
\text { observation(f) }\end{array}$ & \\
accidents & & \\
Keeping the burning candle, hot & 266 & 97 \\
object out of the reach of the & & \\
child & & 97 \\
$\begin{array}{l}\text { Measure to prevent drowning } \\
\text { is to closing the unused well or } \\
\text { ponds }\end{array}$ & 266 & \\
$\begin{array}{l}\text { Measure to prevent foreign } \\
\text { body aspiration is removing all } \\
\text { small objects which the child } \\
\text { can reach }\end{array}$ & 232 & 85 \\
$\begin{array}{l}\text { After fall applying pressure over } \\
\text { the affected side }\end{array}$ & 241 \\
$\begin{array}{l}\text { To prevent the fall there should } \\
\text { be constant supervision of the } \\
\text { child }\end{array}$ & 211 & 77 \\
\end{tabular}




\begin{tabular}{|c|c|c|}
\hline $\begin{array}{l}\text { Supervision, not allowing child } \\
\text { to play along roadside and } \\
\text { keeping child restrained in the } \\
\text { vehicles are preventing method } \\
\text { to reduce risk }\end{array}$ & 186 & 68 \\
\hline $\begin{array}{l}\text { After ingestion of poisonous } \\
\text { thing prevention via induction } \\
\text { of vomiting by putting finger in } \\
\text { throat }\end{array}$ & 255 & 93 \\
\hline $\begin{array}{l}\text { Prevention of home accident via } \\
\text { supervision, locking windows, } \\
\text { closing kitchen doors, removing } \\
\text { hazardous things }\end{array}$ & 184 & 67 \\
\hline
\end{tabular}

If we see the awareness of mothers on prevention of childhood accident then, the prevention of drowning (97\%) and burn(97\%) seems to have more response as compared to others. Preventive measure for poisoning also comes to high level of $97 \%$ awareness by mothers. Furthermore, prevention of fall $(88 \%)$, foreign body aspiration( $85 \%)$, roadside accident $(68 \%)$, home accident $(67 \%)$, have had successive descending order of awareness in parents as shown in above table.

\begin{tabular}{|c|c|c|c|}
\hline $\begin{array}{l}\text { Cognizance } \\
\text { levels of } \\
\text { mothers }\end{array}$ & $\begin{array}{l}\text { Childhood } \\
\text { accident }\end{array}$ & $\begin{array}{l}\text { Chi- } \\
\text { square } \\
\text { test }\end{array}$ & P-value \\
\hline Inadequate & $159(58)$ & \multirow[t]{3}{*}{12.634} & \multirow[t]{3}{*}{$0.013^{*}$} \\
\hline $\begin{array}{l}\text { Moderately } \\
\text { adequate }\end{array}$ & $87(32)$ & & \\
\hline Adequate & $28(10)$ & & \\
\hline
\end{tabular}

* significant level at 0.05

Finally and foremost the crucial correlation of parents level of awareness with childhood as shown in table have statistically significant(0.05) by using chi-square test, such that; inadequate level of knowledge have higher percentage of accident(58\%), followed by moderately adequate (32\%) and adequate (10\%). Thus, less knowledge of awareness have direct impact on unwanted mishaps of kids as shown in above table.

\section{DISCUSSION}

Mishaps of children have very less attention 8 and the awareness of parents regarding the childhood accident in the civil society of our country is nonetheless not known. This particular article want to shrine the data on small scale whether the awareness is there or not and does it matter? In this study the inadequate knowledge level of mothers(159 out of 274) have direct correlation with increment of childhood accident(58\%) as carried out by unsupervised kids $96 \%$. Most of accident are preventable via awareness and improvements in home, however the fact, more than one million children in united kingdom are taken into emergency units 3 . The study carried out at Taddah also have supported the current research statement that majority of mothers (29\%) were uneducated have more child mishaps ${ }^{8}$. The intention of this article is to provide short simple scenario of small community to health policy maker of Nepal that some sort of first aid training program and fundamental awareness are vehemently needed in this country which is supported by the several studies abroad as education 9 , basic knowledge of first aid $^{10}$, prevention and safety ${ }^{11}$ are the needful act to be promoted to reduce the accidents. However, our study revealed that the parents are quite aware of some sort of prevention and method to be done to halt some sort of further unwanted condition after several childhood accidents. The parent shows clear higher percentage of awareness on prevention of drowning (97\%) and burn $(97 \%)$ seems to have more response as compared to others. Preventive measure for poisoning also comes to high level of $97 \%$ awareness by mothers. Furthermore, prevention of fall $(88 \%)$, foreign body aspiration (85\%), roadside accident (68\%), home accident (67\%), have had successive descending order of awareness in parents. The studies carried out by several authors have had to some extent same view as ours 11, 12,13; but study in New York shows ignorance of mother in keeping the items properly in kitchen have sole role in home-made accident via haphazard placement of sharp kitchen instrument be $74 \%$, as in this article the percentage of accident found to be little though $19 \%$ but awareness found to be $67 \%$ quite contrast to it. As we read several articles, accident seems to be the major cause of death during infancy. Nepal in one of the under-developing countries with unique set of geography of Himalayan, hill and terai, and terai having eccentric poses of health services challenges. However, the safety is the fundamental rights and it is the moral and ethical responsibility of policy maker to produce the programme that create awareness among parents, thus society to reduce the mortality due to unwanted childhood accident.

\section{CONCLUSIONS}

Prevention is better than cure. This slogan has deep meaning in a sense, that awareness of parents toward childhood accidents and their scrupulous prevention is mandatory on the right of children. This study though done on small scale on small part of Parsa district can play key role to the policy to have vigilantive and supervision power to see the loopholes that need to be detected and dealing in curative manner. 


\section{REFERENCES}

1. WHO. Word report on profile on child injury prevention. 2008.Geneva. Available on http:/www.searo.who.int/ linkfile/publication.

2. Dorothy R Morlow. Textbook of Pediatric Nursing .6th edition . W.B Saunders Company. 1977;125-6.

3. WHO. List of causes of death by rate.2011. Geneva. Available on http://en.wikipedia.org/wiki/list of causes of death.

4. Hockenberry JM, Wilson D, Wong LD. Health promotion of infant and family. In: Hockenberry JM, Wilson D, Wong LD editors: Wong's Essentials of Pediatric Nursing9: Wong's Essentials of Pediatric Nursing. $9^{\text {th }}$ ed. Elsevier Health Sciences.2012;1194.

5. Walker V, (2002): "Child safety in your home". www. childsafety.com

6. Sabley A. Yassin A, Zaher S. Mother's education and her knowledge about home accident prevention in rural area in Sharkia Governate. IOSR. Journ Nursing $\mathcal{E}$ health sciences.2014; 3:32-40.

7. Scholer SJ, Mitchel EF, Ray AW. Predictors of injury mortality in early childhood. Pediatrics. 1997; 100:342-7.
8. Jan MM, hasanain Fh, et. al, Infants and child safety practices of parents. Saudi Med J. 2000 ;21:1142-6.

9. Schwebel DC, Swart D, Hui SK, Simpson J, Hobe P. Paraffin-related injury in low-income South African communities: knowledge, practice and perceived risk. Bull World Health Organ. 2009;87:700-706.

10. Bollig G, Myklebust AG, Østringen K. Effects of first aid training in the kindergarten-a pilot study. Scand J Trauma Resusc Emerg Med. 2011;19:13.

11. Wang X, Chen N, Shi Z, Zhao Z. An investigation on knowledge-attitude-practice about injury and the related factors among school children's parents in Jinan, China. Int J Inj Contr Saf Promot.2012;19:267-271.

12. Hatamabadi HR, Mahfoozpour S, Alimohammadi H, Younesian S. Evaluation of factors influencing knowledge and attitudes of mothers with preschool children regarding their adoption of preventive measures for home injuries referred to academic emergency centres, Tehran, Iran. Int J Inj Contr Saf Promot. 2013;4:26 .

13. Jan MM, Hasanain FH, Al-Dabbagh AA. Infant and child safety practices of parents. Saudi Med J. 2000;21:1142-1146. 